\title{
HYPERHOMOCYST(E)INEMIA IN CHRONIC STABLE RENAL TRANSPLANT PATIENTS
}

\author{
David José de Barros Machado, Flávio Jota de Paula, Emil Sabbaga and Luiz
} Estevan Ianhez

RHCFAP/3019

MACHADO DJ de B et al. - Hyperhomocyst(e)inemia in chronic stable renal transplant patients. Rev. Hosp. Clín. Fac. Med. S. Paulo 55(5):161-168, 2000.

Purpose: Hyperhomocyst(e)inaemia is an important risk factor for atherosclerosis, which is currently a major cause of death in renal transplant patients. The aim of this study was to assess the influence of immunosuppressive therapy on homocyst(e)inemia in renal transplant recipients.

Methods: Total serum homocysteine (by high performance liquid chromatography), creatinine, lipid profile, folic acid (by radioimmunoassay-RIA) and vitamin B12 (by RIA) concentrations were measured in 3 groups. Group I patients (n=20) were under treatment with cyclosporine, azathioprine, and prednisone; group II $(n=9)$ were under treatment with azathioprine and prednisone; and group III ( $n=7)$ were composed of renal graft donors for groups I and II. Creatinine, estimated creatinine clearance, cyclosporine trough level, lipid profile, folic acid, and vitamin B12 concentrations and clinical characteristics of patients were assessed with the aim of ascertaining determinants of hyperhomocyst(e)inemia.

Results: Patient ages were $48.8 \pm 15.1$ yr (group I), $43.3 \pm 11.3$ yr (group II); and $46.5 \pm 14.8$ yr (group III). Mean serum homocyst(e)ine (tHcy) concentrations were $18.07 \pm 8.29 \mathrm{mmol} / \mathrm{l}$ in renal transplant recipients; $16.55 \pm 5.6 \mathrm{mmol} / \mathrm{l}$ and $21.44 \pm 12.1$ $\mathrm{mmol} / \mathrm{l}$ respectively for group I (with cyclosporine) and group II (without cyclosporine) (NS). In renal donors, tHcy was significantly lower $(9.07 \pm 3.06 \mathrm{mmol} / \mathrm{l}$; group I + group II vs. group III, $\mathrm{p}<0.008)$. There was an unadjusted correlation $(\mathrm{p}<0.10)$ between age $(r=0.427 ; p<0.005)$ body weight $(r=0.412 ; p<0.05)$, serum creatinine $(r=0.427 ; p<0.05)$, estimated creatinine clearance $(r=0.316$; $\mathrm{p}<0.10)$, and tHcy in renal recipients (group I $+\mathrm{II})$. Independent regressors $\left(\mathrm{r}^{2}=0.46\right)$ identified in the multiple regression model were age (coefficient $=0.253 ; \mathrm{p}=0.009)$ and serum creatinine (coefficient $=8.07 ; \mathrm{p}=0.045)$. We found no cases of hyperhomocyst $(\mathrm{e})$ inemia in the control group. In contrast, $38 \%$ of renal recipients had hyperhomocyst(e)inemia: 7 cases (35\%) on cyclosporine and 4 (45\%) without cyclosporine, based on serum normal levels.

Conclusions: Renal transplant recipients frequently have hyperhomocyst(e)inemia. Hyperhomocyst(e)inemia in renal transplant patients is independent of the scheme of immunosuppression they are taking. The older the patients are and the higher are their serum creatinine levels, the more susceptible they are to hyperhomocyst(e)inemia following renal transplantation.

DESCRIPTORS: Homocysteine. Renal transplantation. Cyclosporine. Azathioprine. Prednisone.

Homocysteine is a sulfur-containing amino acid formed from methionine metabolism. Hyperhomocyst(e) inemia is an independent risk factor for the development of atherosclerosis ${ }^{1,2}$.

In 1969, McCully described extensive arterial thrombosis and atherosclerosis in 2 children, establishing the linkage between homocysteine and vascular disease ${ }^{3}$. Since then, many reports have reaffirmed this link-

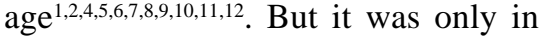
1994 that cardiovascular disease was correlated with hyperhomocyst(e) inemia in renal transplant patients ${ }^{13}$. Efforts to identify factors known to influence homocysteine metabolism succeeded; however, although homocys-

From the Division of Urology, Hospital das Clínicas, Faculty of Medicine, University of São Paulo. teine concentrations can be successfully modulated with treatment ${ }^{14,15}$, we do not yet know the influence of such modulation on cardiovascular disease.

Immunosuppression after renal transplantation potentially could enhance hyperhomocyst(e)inemia - and its future modulation prevent it. We tested the former hypothesis - that immunosuppression after renal transplantation would enhance hyperhomo- 
cyst(e)inemia - in a cross-sectional study on three groups of patients divided according to presence or absence of cyclosporine in the treatment regimen. We have also assessed the factors known to influence homocysteine metabolism in this population.

\section{SUBJECTS AND METHODS}

Fasting blood samples were collected for analysis of total homocysteine (tHcy) by high-performance liquid chromatography with fluorescence detection. Normal serum total homocysteine concentration values ranged from 5.5 to $17 \mathrm{mmol} / \mathrm{l}$.

Plasma folate and vitamin B12 levels were measured by radioimmunoassay. Serum creatinine, total cholesterol, LDL cholesterol (low-density lipoprotein), HDL cholesterol (high-density lipoprotein), and triglycerides were determined using standard automated clinical chemistry laboratory techniques. Creatinine clearance was estimated from the Cochkcroft-Gault formula $^{16}$. Whole blood cyclosporine through levels were analyzed with TDx Immunosuppressant Drug Assays Cyclosporine Monoclonal Whole
Blood (Abbot Laboratories).

Twenty-nine renal transplant patients were studied at least 12 months after transplantation, undergoing treatment with fixed doses of immunosuppressive drugs for 6 months and having serum creatinine levels of less than $2.0 \mathrm{mg} / \mathrm{dl}$. Study patients were not under treatment with any vitamin supplement following the transplantation. End-stage renal disease was due to chronic glomerulonephritis $(\mathrm{n}=11)$, chronic pyelonephritis $(\mathrm{n}=5)$, nephrosclerosis $(\mathrm{n}=5)$, diabetic nephropathy $(n=3)$, polycystic kidney disease $(n=2)$ or undetermined cause $(n=3)$.

Patients were divided into 2 groups according to immunosuppression therapy:

Group I: 20 renal transplant patients on cyclosporine, azathioprine, and prednisone;

Group II: 9 renal transplant patients on azathioprine and prednisone;

And the third group enrolled comprised renal donors (control group):

Group III: 7 renal graft donors for groups I and II.

Results were expressed as mean \pm standard deviation (SD). Continuous variables were compared by t-test, and the chi-square test was applied for es- timating the occurrence of categorical variables. Pearson Product Moment correlation was used for unadjusted correlation between continuous variables. Multiple regression analysis was performed to identify independent predictors of tHcy. Statistical significance was defined as tests with a probability of $<0.05$. The statistical analyses were performed in SigmaStat 2.0 software.

\section{RESULTS}

Characteristics of patients and control groups are summarized in Table 1.

The mean plasma homocyst(e) inemia concentration was $18.07 \pm 8.29$ $\mathrm{mmol} / \mathrm{l}$ in renal transplant recipients: $16.55 \pm 5.6 \mathrm{mmol} / \mathrm{l}$ (group I, with cyclosporine), and $21.44 \pm 12.1 \mathrm{mmol} /$ 1 (group II, without cyclosporine) (NS).In renal donors, tHcy was significantly lower $(9.07 \pm 3.06 \mathrm{mmol} / \mathrm{l}$; group I + group II vs. group III, $\mathrm{p}<0.008)$.

Pearson correlation was tested using age, body weight, dialysis duration before transplantation, transplant duration, serum creatinine, estimated creatinine clearance, cholesterol, HDL cholesterol and LDL - cholesterol, trig-

Table 1 - Clinical and laboratorial characteristics of renal transplant patients and control groups.

\begin{tabular}{|c|c|c|c|}
\hline & Group I & Group II & Group III \\
\hline $\mathbf{n}$ & 20 & 9 & 7 \\
\hline Age (yr; mean + SD) & $48.8 \pm 15.1$ & $43.3 \pm 11.3$ & $46.5 \pm 14.8$ \\
\hline Sex (number female) & 7 & 2 & 6 \\
\hline Serum creatinine $(\mathrm{mg} / \mathrm{dl}$; mean $\pm \mathrm{SD})$ & $1.18 \pm 0.26$ & $1.33 \pm 0.44$ & $0.97 \pm 0.18$ \\
\hline Body weight $(\mathrm{Kg} ;$ mean \pm SD $)$ & $72.5 \pm 16.8$ & $66.8 \pm 11.9$ & \\
\hline Estimated creatinine clearance $(\mathrm{ml} / \mathrm{min} ;$ mean $\pm \mathrm{SD})$ & $73.2 \pm 25.1$ & $69.5 \pm 20.1$ & \\
\hline Transplant duration (months; mean \pm SD) & $49.4 \pm 28.2$ & $58.2 \pm 18.2$ & \\
\hline Dialysis duration before transplantation (months; mean \pm SD) & $32.4 \pm 25.5$ & $39.8 \pm 13.3$ & \\
\hline tHcy $($ micromol/l; mean \pm SD) & $16.5 \pm 5.6$ & $21.4 \pm 12.1$ & $9.1 \pm 3.0 * *$ \\
\hline Folate $(\mathrm{ng} / \mathrm{ml} ;$ mean \pm SD) & $7.7 \pm 3.5$ & $7.4 \pm 1.2$ & $6.7 \pm 1.6 * *$ \\
\hline Vitamin B12 (pg/ml; mean \pm SD) & $315.0 \pm 139.1$ & $418.0 \pm 397.0$ & $350.0 \pm 176.5$ \\
\hline Triglicerides $(\mathrm{mg} / \mathrm{dl}$; mean \pm SD) & $219.4 \pm 115.3$ & $154.2 \pm 103.3$ & $129.7 \pm 64.2$ \\
\hline Cholesterol $(\mathrm{mg} / \mathrm{dl}$; mean $\pm \mathrm{SD})$ & $227.8 \pm 40.9$ & $183.8 \pm 29.3 *$ & $194.4 \pm 36.7$ \\
\hline HDL-cholesterol (mg/dl; mean \pm SD) & $51.5 \pm 11.4$ & $54.0 \pm 12.0$ & $50.1 \pm 5.3$ \\
\hline LDL-cholesterol (mg/dl; mean \pm SD) & $144.0 \pm 43.1$ & $105.7 \pm 16.7 *$ & $116.2 \pm 34.1$ \\
\hline
\end{tabular}

$* \mathrm{p}<0.05$ group I vs. group II

$* * \mathrm{p}<0.05$ group I + II vs. group III 
lycerides, folate level, vitamin B12 level, azathioprine, and prednisone doses vs. homocyst(e)inemia. Unadjusted correlations $(\mathrm{p}<0.10)$ were found between age $(r=0.427 ; \mathrm{p}<0.005)$, body weight $(\mathrm{r}=0.412 ; \mathrm{p}<0.05)$, serum creatinine $(r=0.427 ; p<0.05)$, estimated creatinine clearance $(\mathrm{r}=0.316 ; \mathrm{p}<0.10)$, and tHcy in renal recipients (group I + II). There was no statistically significant correlation between sex and tHcy. Independent regressors $\left(\mathrm{r}^{2}=0.46\right)$ identified in the multiple regression model were age (coefficient $=0.253 ; \mathrm{p}=0.009$ ) and serum creatinine (coefficient $=8.07$; $\mathrm{p}=0.045$ ).

Total serum homocysteine in the cyclosporine-treated group had no one independent regressor in this study, when age, body weight, dialysis duration before transplantation, transplant duration, serum creatinine, cyclosporine trough level, estimated creatinine clearance, cholesterol, HDL-cholesterol and LDL-cholesterol, triglycerides, folate level, vitamin B12 level, azathioprine dose, prednisone dose, and cyclosporine dose were included.

We found no cases of hyperhomocyst(e)inemia in the control group. In contrast, $38 \%$ of renal recipients had hyperhomocyst(e)inemia: 7 cases $(35 \%)$ in the cyclosporine-treated group and 4 (45\%) in the group not receiving cyclosporine, based on plasmatic normal levels. If there was a positive and direct relationship between serum and plasma homocysteine levels, we would state, based on the Kang et al. classification ${ }^{12}$, that for patients receiving cyclosporine, $35 \%$ had moderate hyperhomocyst(e)inemia; for patients not receiving cyclosporine (group II), $33 \%$ had moderate and $12 \%$ had intermediate hyperhomocyst(e) inemia.

\section{DISCUSSION}

Homocysteine is a sulfur-containing non-essential amino acid that is formed as a product of methionine metabolism. Its chemical structure is 2amin-4-mercaptobutanoic acid.

Methionine is converted to homocysteine through S-adenosyl methionine. Then homocyst(e)ine undergoes either remethylation or transsulfuration. In the remethylation pathway, homocysteine is salvaged by the acquisition of a methyl group in a reaction catalyzed by methionine synthase. Vitamin B12 (cobalamin) is the precursor of methylcobalamin, which is the cofactor for methionine synthase, and N5- methyl-tetrahydrofolate is the methyl donor in this reaction. Remethylation can also be catalyzed by betaine-homocysteine methyl transferase $\mathrm{e}^{17,18,19,20,21,22,23,24,25,26}$.

Under conditions in which an excess of methionine is present or cysteine synthesis is required, homocysteine condenses with serine to form cystathionine in a reaction catalyzed by the vitamin-B6-dependent enzyme, cystathionine $\beta$-synthase s, $18,19,20,22,24,25^{\text {. }}$. Cystathionine is subsequently hydrolyzed to form $\alpha$-ketobutyrate and cysteine, which may in turn be incorporated into glutathione or further metabolized to sulfate and excreted in the urine $^{18,26}$.

Clinical studies involving homocysteine generally rely on the measurement of total plasma homocysteine, which includes homocysteine, mixed disulfides involving homocysteine, homocysteine thiolactone, free homocysteine, and protein-bound homocysteine ${ }^{17,27}$. The sum of all free and protein-bound forms is referred as total homocysteine (tHcy) or as homocyst(e)ine to emphasize the uncertain distribution of reduced sulfhydryl and oxidized disulfide moieties ${ }^{28}$. This correct but cumbersome convention is frequently overlooked but needs to be acknowledged ${ }^{17}$. Normal total plasma homocysteine concentration ranges from 5 to $15 \mathrm{mmol}$ per liter in the fasting state ${ }^{22}$, and serum levels are known to be higher ${ }^{29,30}$ in the fasting state. Kang et al. have classified hyperhomocyst(e)inemia as moderate (from 15 to $30 \mathrm{mmol}$ per liter), intermediate (> 30 to $100 \mathrm{mmol}$ per liter), and severe (>100 mmol per liter) on the basis of fasting plasma measured concentrations ${ }^{12}$. An oral challenge $(100 \mathrm{mg} / \mathrm{kg})$ can be given to persons suspected of hyperhomocyst(e)inemia who have normal fasting homocyst(e)ine levels. Plasma homocyst(e)ine concentrations are determined before methionine challenge and 4 and 8 hours afterwards. Hyperhomocyst(e)inemia is considered to be present if the concentration of tHcy is more than 2 standard deviations above the mean ${ }^{11}$. The oral methionine challenge is more useful for subjects with cystathionine- $\beta$-synthase deficiency than for those with methylenetetrahydrofolate reductase deficiency ${ }^{4,20}$.

There are genetic and acquired causes of homocyst(e)inemia. Rare inborn errors of metabolism result in elevation of plasma and urine homocysteine. The homozygous deficiency of cystathionine $\beta$-synthase is the most common cause and is associated with plasma tHcy levels up to $400 \mathrm{mmol}$ per liter ${ }^{20}$. Atherothrombotic complications frequently develop in young adulthood and are often fatal ${ }^{9}$. Heterozygotes typically have plasma levels in the range of 20 to $40 \mathrm{mmol}$ per liter ${ }^{1,4}$. A homozygous deficiency of N5-N10methylene-tetrahydrolfolate reductase (MTHFR) carries a much worse prognosis, in part due to the complete lack of effective therapy ${ }^{20}$. Kang et al. reported a more common genetic defect that is phenotypically expressed as a thermolabile form of MTHFR that has a prevalence of $5 \%$ in the general population and $17 \%$ among patients with coronary disease ${ }^{31,32}$. Deficiencies in vitamin cofactors required for homocysteine metabolism, like folate, vitamin $\mathrm{B} 12$, and B6, may promote 
hyperhomocyst(e)inemia, and supplementation can normalize concentrations of homocysteine ${ }^{14,15,21,33,34}$. Negative correlations have been related between folate, cobalamin, and tHcy ${ }^{1,6,35,36,37,38,39,40,41}$. Several drugs can interfere with the metabolism of homocysteine such as methotrexate, phenytoin, and theophylline ${ }^{20}$.

In spite of in vitro studies reporting renal metabolism of homocysteine, and in vivo studies in which the concentration of homocysteine in the plasma of rats was increased due to its substantial uptake and metabolism by the kidney ${ }^{42,43,44}$, van Guldener et al. showed no net renal extraction of homocysteine in fasting humans $\mathrm{s}^{45,46}$. These findings rekindle a search for "uremia-induced" extrarenal defects in homocysteine metabolism ${ }^{18}$. Although it was said that urinary homocysteine excretion was minimal ${ }^{42}$, hyperfiltrating diabetic subjects with supernormal glomerular filtration rates may have subnormal fasting tHcy levels ${ }^{47}$. Indeed, it should be stressed that glomerular filtration rate and cystatin $\mathrm{C}$ are independent determinants of tHcy, and they are much better determinants than is creatinine concentration ${ }^{48,49}$. Although there is a direct relationship between tHcy and KT/V (an index of dialysis adequacy), the dialytic amount of tHcy did not seem to contribute significantly to its removal ${ }^{38}$.

In 1969, McCully described prominent arterial damage in patients with a deficiency in methionine metabolism and homocysteinemia and hypothesized that homocysteine derivatives played a role in the pathogenesis of atherosclerosis ${ }^{3}$. Histopathologic hallmarks of homocysteine-induced vascular injury include intimal thickening, elastic lamina disruption, smooth muscle hypertrophy, marked platelet accumulation, and the formation of platelet-enriched occlusive thrombi ${ }^{3,5}$. The postulated effects involve oxidative damage to vascular endothelial cells and increased proliferation of vascular smooth cells after oxidative metabolism of homocysteine to homocystine and homocysteine thiolactone. Oxidative modification of low-density lipoprotein (LDL) promotes the formation of foam cells, which in turn yields another source of reactive species ${ }^{50}$. A direct endothelial cell injury can also occur $^{51}$. It seems that prostacyclin production is unlikely to result from homocysteine effects ${ }^{52,53,54}$. Prolonged exposure of endothelial cells to homocysteine impairs production of nitric oxide $^{55}$ and alters the normal antithrombotic phenotype of the endothelium by attenuation of endothelial cell tissue-plasminogen-activator binding sites ${ }^{56,57}$, activation of factor $\mathrm{V}^{58}$, inhibition of protein $^{59,60}$ and heparan sulfate $^{6}$ and decreasing endothelial antithrombotic activity due to changes in thrombomodulin function ${ }^{60}$.

There is abundant epidemiological evidence of the association between hyperhomocyst(e)inemia and atherothrombosis either in normal or endstage renal failure population $^{1,2,46,7,8,9,10,11,12}$.

Patient death from cardiovascular causes is an important reason for transplant failure over time ${ }^{62}$. Fifty to sixty percent of deaths are directly attributable to cardiovascular disease. Future advances in long-term renal graft survival will depend largely on the success of preventing myocardial infarction and death in this patient population ${ }^{63}$.

Renal transplant recipients are prone to atherosclerotic complications, and risk factors independently associated in a multivariate analysis after accounting for pretransplant vascular disease were: increasing patient age, diabetes mellitus, male gender, cigarette smoking, hypertension, and elevated serum cholesterol levels. The data had also suggested that an increased prevalence of known risk factors explains the high incidence of cardiovascular disease in the renal transplant recipi- ent $^{64}$. Immunosuppressive drugs that prevent allograft rejection could exacerbate atherosclerosis. However, this possibility could not explain all cases, so efforts were made to identify other risk factors.

Fasting hyperhomocyst(e)inemia is an independent risk factor for coronary artery disease, stroke, peripheral vascular atherosclerosis, and for arterial and venous thromboembolism. The interaction of hyperhomocyst(e)inemia with hypertension and smoking is strong, and the combined effect is more than multiplicative. The combined effect of homocysteine and cholesterol is additive ${ }^{10}$.

Massy et al. were pioneers in the study of homocysteine metabolism in renal transplant patients, and they found by stepwise discriminant analysis and by logistic regression analysis in 42 patients that homocysteine was also a risk factor associated with cardiovascular disease in this population ${ }^{13}$.

Total homocysteine is significantly increased in renal transplant patients $^{35,36,37,40,41,65}$ as compared to healthy controls $^{35,65}$ or a matched renal dysfunction group ${ }^{35,40,65}$.

Determinants of homocyst(e)ine concentration in renal transplant patients are listed in table 2.

In 1996, Arnadottir et al. reported that renal transplant recipients on cyclosporine had significantly higher plasma homocyst(e)inemia than those not on cyclosporine ( $19.7 \pm 7.6$ vs. 16.2 $\pm 4.8 \mathrm{mmol} / \mathrm{l}$, mean \pm S.D $)^{35}$. But in 1998 , they described no correlation between plasma homocyst(e)ine and cyclosporine concentration or doses of cyclosporine, prednisone, and azathioprine $^{40}$. It is not known how cyclosporine could interfere in homocysteine metabolism, but cyclosporine could be a methyl donor, since during its hepatic metabolism, hydroxylation and $\mathrm{N}$ demethylation are important reactions ${ }^{66}$. Moreover, Ducloux et al reported that patients with or without cyclosporine 
Table 2 - Determinants of homocyst(e)in concentration in renal transplant patients.

\begin{tabular}{lll}
\hline Reference & Hyperhomocyst(e)inemia $\mu \mathrm{mol} / 1$ & Determinants \\
\hline Arnadottir et al. ${ }^{19}$ & $27.7 \pm 14.8^{* *}$ & glomerular filtration rate, creatinine concentration, plasma folate level \\
Ducloux et al. ${ }^{6}$ & $21.4 \pm 10.2^{* *}$ & glomerular filtration rate, creatinine concentration, plasma folate level \\
Ducloux et al. ${ }^{5}$ & $21.3 \pm 9.7^{* *}$ & glomerular filtration rate, plasma folate level \\
Arnadottir et al. ${ }^{4}$ & $19.0 \pm 6.9^{* *}$ & $\begin{array}{l}\text { glomerular filtration rate, cyclosporine-treated group, sex, plasma folate } \\
\text { level }\end{array}$ \\
Machado et al. ${ }^{20}$ & $18.4 \pm 9.6^{*}$ & glomerular filtration rate, creatinine concentration \\
Machado et al. - this paper & $18.0 \pm 8.2^{*}$ & $\begin{array}{l}\text { creatinine concentration, age, weight } \\
\text { creatinine concentration, age, pyridoxal 5'-phosphate level, plasma } \\
\text { folate level, plasma vitamin B12 level }\end{array}$ \\
Boston et al. ${ }^{22}$ & $15.6^{* *}$ & $\begin{array}{l}\text { glomerular filtration rate, plasma folate level, MTHFR genotype, sex, } \\
\text { body index mass, age and plasma vitamin B12 level }\end{array}$ \\
Födinger et al. ${ }^{15}$ & $17.6 \pm 9.2^{* *}$ & \\
\hline$*$ - serum level & &
\end{tabular}

had similar plasma homocyst(e)ine concentrations ${ }^{36,37}$. Woodside et al found no difference in homocysteinemia between patients receiving cyclosporin $(n=39$, homocysteine $11.0 \pm 1.5 \mathrm{mmol} / \mathrm{l}$ ), and patients receiving prednisolone + azathioprine $(\mathrm{n}=16,10.8 \pm 1.6 \mathrm{mmol} / \mathrm{l}$, mean \pm S.D.), although there was a significant correlation between homocysteine and serum cyclosporin concentration in the sub-group of patients receiving that immunosuppressive regimen $(\mathrm{r}$ $=0.42, \mathrm{P}<0.05)^{67}$. Gilfix et al showed a negative correlation of tHcy to cyclosporine when using C2 levels (level of cyclosporine measured in the second hour after administration), but which was consistent with the negative correlation between creatinine concentration and $\mathrm{C}^{68}$. In our previous study, although tHcy was similar under the two schemes of immunosuppressors, there was a strong negative correlation between tHcy and the cyclosporine trough level $(\mathrm{r}=-0.79 \text { and } \mathrm{p}=0.01)^{65}$. As yet, we have not found a difference between tHcy levels with or without cyclosporine or an effect of cyclosporine trough level on homocyst (e)inemia.
Azathioprine, another immunosuppressive drug, causes absolute or relative deficiency in folate and/or cobalamin, a condition also reported to increase homocyst(e)inemia.

Födinger et al observed no effect of azathioprine on homocysteine metabo$\operatorname{lism}^{39}$. In contrast, Mazouz et al concluded that the addition of azathioprine to the standard immunosuppressive regimen further increased Hcy serum levels in renal transplant recipients, which could be mediated by absolute or relative deficiency in folate ${ }^{69}$.

In adult male rats, mean plasma homocysteine concentration after treatment with cortisol was substantially lower, compared with the level of plasma homocysteine in the control group, indicating a significant protective effect of steroid on plasma homocysteine levels ${ }^{70}$.

We did not observe a correlation between azathioprine or prednisone doses and homocyst(e)inemia in either of the recipient groups or between cyclosporine doses in the group taking cyclosporine.

It had been previously reported that there was no difference in homocysteine levels between individuals treated with tacrolimus and cyclosporine, and there was no correlation between homocysteine and immunosuppressant trough levels or the development of histologically diagnosed chronic graft nephropathy ${ }^{71}$.

Although vitamin B6 treatment resulted in a $22.1 \%$ reduction in geometric-mean post-methionine-loading increases in plasma total homocysteine levels, and folic acid plus vitamin B12 treatment caused a $26.2 \%$ reduction in geometric-mean fasting plasma total homocysteine levels ${ }^{15}$, their effect on cardiovascular disease is not known.

We must stress that hyperhomocyst(e)inemia is an important problem in the follow-up of renal transplant recipients. Renal recipients with renal function loss and the older recipients are the most at risk population. Since hyperhomocyst(e)inemia increases cardiovascular disease risk and patient survival, efforts have to be made to search for other possible determinants of homocyst(e)inemia and to reduce it. 
MACHADO DJ de B e col. - Hiperhomocisteinemia em transplantados renais crônicos. Rev. Hosp. Clín. Fac. Med. S. Paulo 55(5):161-168, 2000.

Objetivos: A hiper-homocisteinemia é um fator de risco importante para aterosclerose e, esta é uma das principais causas de óbito em transplantados renais. O objetivo deste estudo é avaliar a influência da terapêutica imunossupressora na homocisteinemia de receptores de transplante renal.

Casuística e Método: Vinte e nove pacientes foram divididos em dois grupos: grupo I $(n=20)$ - pacientes transplantados renais em uso de ciclosporina, azatioprina e prednisona; grupo II $(n=9)$ - pacientes transplantados renais em uso de azatioprina e prednisona; grupo III $(\mathrm{n}=7)$ doadores de rim para pacientes dos grupos I e II, constituíram o grupo controle. O nível sérico de creatinina e o clearance estimado de creatinina, o nível sérico de ciclosporina, o perfil de lipídeos, a concentração de ácido fólico e vitamina B12 e as características clínicas dos indivíduos foram avaliados na procura de determinantes da homocisteinemia. A concentração sérica de homocisteína foi medida através da cromatografia de alta resolução e a concentração de ácido fólico e vitamina B12 por radioimunoensaio.

Resultados: Os pacientes tinham $48.8 \pm 15.1$ aa e $43.3 \pm 11.3$ aa respectivamente, nos grupos I e II e os doadores $46.5 \pm 14.8$ aa. A homocisteinemia sérica média dos pacientes transplantados renais foi de $18.07 \pm$ $8.29 \mathrm{mmol} / \mathrm{l}$. No grupo de pacientes em uso de ciclosporina foi de $16.55 \pm$ $5.6 \mathrm{mmol} / \mathrm{l}$ e no grupo sem ciclosporina foi de $21.44 \pm 12.1 \mathrm{mmol} / \mathrm{l}$ (NS). No grupo de doadores foi significativamente menor $(9.07 \pm 3.06$ $\mathrm{mmol} / \mathrm{l}$; grupo I + grupo II vs. grupo III, $\mathrm{p}<0.008$ ), não tendo sido encontrado nenhum caso de hiper-homocisteinemia. Houve correlação entre idade $(r=0.427 ; p<0.005)$, peso corpóreo $(\mathrm{r}=0.412 ; \mathrm{p}<0.05)$, creatinina sérica $(\mathrm{r}=0.427 ; \mathrm{p}<0.05)$, clearance estimado de creatinina $(r=0.316 ; p<0.10)$ e tHcy nos pacientes transplantados renais. Porém no modelo de regressão múltipla, só foram significativos idade (coeficiente $=0.253 ; \mathrm{p}=0.009$ ) e creatinina sérica (coeficiente $=8.07 ; \mathrm{p}=0.045$ ). No grupo de transplantados renais encontramos 38\% de casos com hiperhomocist(e)inemia sendo sete casos (35\%) do grupo I e quatro casos (45\%) do grupo II, baseado nos níveis séricos normais.

Conclusões: Os pacientes transplantados renais apresentam hiperhomocisteinemia independente do esquema de imunossupressão que estejam utilizando. A hiper-homocisteinemia após o transplante renal tem como determinantes a idade do receptor e o seu nível de creatinina sérica.

DESCRITORES: Homocisteína. Transplante renal. Ciclosporina. Azatioprina. Prednisona.

\section{REFERENCES}

1. CLARKE R, DALY L, ROBINSON K et al. - Hyperhomocysteinemia: an independent risk factor for vascular disease. N Engl J Med 1991; 324: 1149- 1155

2. SELHUB J, JACQUES PF, BOSTON AG et al. - Association between plasma homocysteine concentration and extracranial carotid-artery stenosis. N Engl J Med 1995; 332: 286-291.

3. MCCULLY KS - Vascular pathology of homocysteinemia: implication for the pathogenesis of arteriosclerosis. Am J Pathol 1969; 56:111128.

4. WILCKEN DE, REDDY SG \& GUPTA VJ - Homocysteinemia, ischemic heart disease, and the carrier state for homocystinuria. Metabolism 1983; 32: 363-370.
5. MCCULLY KS \& RAGSDALE BD - Production of arteriosclerosis by homocysteinemia. Am J Pathol 1970; 61: 1-12.

6. DENNIS VW \& ROBINSON K - Homocysteine and vascular disease in end-stage renal disease. Kidney Int (Suppl) 1996; 57: S11-S17.

7. BLACHER J, MONTALESCOT G, ANKRI A et al. Hyperhomocysteinemia in coronary artery disease. Apropos of a study on 102 patients. Arch Mal Coeur Vaiss 1996; 89: 12411246.

8. STAMPFER MJ, MALINOW MR, WILLET WC et al. - A prospective study of plasma homocyst(e)ine and risk of myocardial infarction in US physicians. JAMA 1992; 268: 877-881. 
9. CAREY MC, DONOVAN DE, FITZGERALD O et al. Homocystinuria. A clinical and pathological study of nine subjects in six families. Am J Med 1968; 45:7-25.

10. PRASAD K - Homocysteine, a Risk Factor for Cardiovascular Disease. Int J Angiol 1999; 8: 76-86.

11.DUDMAN NP, WILCKEN DE, WANG J et al. - Disordered methionine/ homocysteine metabolism in premature vascular disease. Its occurrence, cofactor therapy, and enzymology. Arterioscler Thromb 1993; 13: 1253-1260.

12. KANG SS, WONG PW \& MALINOV MR - Hyperhomocyst(e)inemia as a risk factor for occlusive vascular disease. Annu Rev Nutr 1992; 12: 279-298.

13. MASSY ZA, CHADEFAUX-VEKEMANS B, CHEVALIER A et al. Hyperhomocysteinaemia: a significant risk factor for cardiovascular disease in renal transplant recipients. Nephrol Dial Transplant 1994; 9: 1103-1108.

14. ARNADOTTIR M \& HULTBERG B - Treatment with high-dose folic acid effectively lowers plasma homocysteine concentration in cyclosporine-treated renal transplant recipients. Transplantation 1997; 64: 1087-1088.

15. BOSTOM AG, GOHH RY, BEAULIEU AJ et al. - Treatment of hyperhomocysteinemia in renal transplant recipients. A randomized, placebo-controlled trial. Ann Intern Med 1997; 127: 1089-1092.

16. COCHKCROFT DW \& GAULT MM - Prediction of creatinine clearance from serum creatinine. Nephron 1976; 16: 31- 41.

17. DENNIS VW, NURKO S \& ROBINSON K - Hyperhomocysteinemia: detection, risk assessment, and treatment. Curr Opin Neprol Hypertens 1997; 6: 483-488.

18. BOSTON AG \& CULLETON BF - Hyperhomocysteinemia in chronic renal disease. J Am Soc Neprol 1999; 10: 891-890.

19. DUDMAN NP, GUO XW, GORDON RB et al. - Human homocysteine catabolism: three major pathways and their relevance to development of arterial occlusive disease. J Nutr 1996; 126: 1295S-1300S.

20. WELCH GN \& LOSCALZO J - Homocysteine and atherothrombosis. N Engl J Med 1998; 338: 1042-1052.

21. NEVE J - The nutritional importance and pharmacologic effects of cobalt and vitamin B 12 in man. J Pharm Belg 1991; 46: 271-280.

22. UELAND PM \& REFSUM H - Plasma homocyst(e)ine, a risk factor for vascular disease: plasma levels in health, disease, and drug therapy. J Lab Clin Med 1989; 114: 473-501.

23. FINKELSTEIN JD, HARRIS BJ \& KYLE WE - Methionine metabolism in mammals : kinetic study of betaine-homocysteine methyltransferase. Arch Biochem Biophys 1972; 153: 320-324.

24.FINKELSTEIN JD - The metabolism of homocyst(e)ine: pathways and regulation. Eur J Pediatr 1998; 157:S40-S44.

25. FINKELSTEIN JD \& MARTIN JJ - Methionine metabolism in mammals. Adaptation to methionine excess. J Biol Chem 1986; 261: $1582-1587$

26. Finkelstein JD, Martin JJ \& Harris BJ - Methionine metabolism in mammals. The methionine spring effect of cysteine. J Biol Chem 1988; 263: 11750-11754.
27. UELAND PM, MANSOOR MA, GUTTORMSEN AB et al. - Reduced, oxidized and protein-bound forms of homocysteine and other aminothiols in plasma comprise the redox thiol status - a possible element of the extracellular antioxidant defense system. J Nutr 1996; 126: 1281S-1284S.

28. MUDD SH \& LEVY HL - Plasma homocyst(e)ine or homocysteine? N Engl J Med 1995; 33: 325.

29. BRAUN WE, PROTIVA, DA, GIFFORD RW et al. Hyperhomocysteinemia and other coronary risk factors in 20-year renal transplant recipients (level $5 \mathrm{~A}$ ) with and without coronary heart disease. Transpl Proc 1999; 31: 1280-1282.

30. JACOBSEN DW, GATAUTIS VJ, GREEN R et al. - Rapid HPLC determination of total homocysteine and other thiols in serum and plasma: sex differences and correlation with cobalamin and folate concentrations in healthy subjects. Clin Chem 1994; 40: 873-881.

31.KANG SS, ZHOU J, WONG PWK et al. - Intermediate homocysteinemia: a thermolabile variant of methylenetetrahyfolate reductase. Am J Hum Gen 1988; 43: 414-421.

32. KANG SS, WONG PWK, SUSMANO A et al. - Thermolabile methylenetetrahydrofolate reductase: an inherited risk factor for coronary disease. Am J Hum Genet 1991; 48: 536-545.

33. KANG SS, WONG PWK \& NORUSIS M - Homocysteinemia due to folate deficiency. Metabolism 1987; 36: 458-462.

34. DUDMAN NPB, TYRRELL PA \& WILCKEN DEL Homocysteinemia: depressed plasma serine levels. Metabolism 1987; 36: 198-201.

35. ARNADOTTIR M, HULTBERG B, VLADOV V et al. Hyperhomocysteinemia in cyclosporine-treated renal transplant recipients. Transplantation 1996; 61: 509-512.

36. DUCLOUX D, RUEDIN C, GIBEY R et al. - Prevalence, determinants, and clinical significance of hyperhomocyst(e)inaemia in renaltransplant recipients. Nefrol Dial Transplant 1998; 13: 2890-2893.

37. DUCLOUX D, FOURNIER V, REBIBOU J-M et al. Hyperhomocyst(e)inemia in renal transplant recipients with or without cyclosporine. Clin Neprol 1998; 49: 232-235.

38. ARNADOTTIR M, BERG AL, HEGBRANT B et al. - Influence of haemodialysis on plasma total homocysteine concentration. Neprol Dial Transplant 1999; 14: 142-146.

39. FÖDINGER M, WÖLFL G, FISCHER G et al. - Effect of MTHFR $677 \mathrm{C}>\mathrm{T}$ on plasma total homocysteine levels in renal graft recipients. Kidney Int 1999; 55: 1072-1080.

40. ARNADOTTIR M, HULTBERG B, WAHLBER GJ et al. - Serum total homocysteine concentration before and after renal transplantation. Kidney Int 1998; 54: 1380-1384.

41. BOSTOM AG, GOHH RY, BEAULIEU AJ et al. - Determinants of fasting plasma homocysteine levels among chronic stable renal transplant recipients. Transplantation 1999; 68: 257-260.

42. BOSTON A, BROSNAN JT, HALL B et al. - Net uptake of plasma homocysteine by the rat kidney in vivo. Atherosclerosis 1995; 16: 59-62.

43. HOUSE JD, BROSNAN ME, BROSNAN JT - Renal uptake and excretion of homocysteine in rats with acute hyperhomocysteinemia. Kidney Int 1998; 54: 1601-1607. 
44. FOREMAN JW, WALD H, BLUMBERG G et al. - Homocystine uptake in isolated rat renal cortical tubules. Metabolism 1982; 31: 613619.

45. VAN GULDENER C, DONKER AJ, JAKOBS C et al. - No net renal extraction of homocysteine in fasting humans. Kidney Int 1998; 54: $166-169$.

46. VAN GULDENER C, JANSSEN MJ, STEHOUWER CD et al. - The effect of renal transplantation on hyperhomocysteinaemia in dialysis patients, and the estimation of renal homocysteine extraction in patients with normal renal function. Neth J Med 1998; 52: $58-64$

47. WOLLESEN F, BRATTSTROM L, REFSUM H et al. - Plasma total homocysteine and cysteine in relation to glomerular filtration rate in diabetes mellitus. Kidney Int 1999 ; 55: 1028-1035.

48. ARNADOTTIR M, HUTBERG B, NILSSON-EHLE P et al. - The effect of reduced glomerular filtration rate on plasma total homocysteine concentration. Scand J Clin Lab Invest 1996; 56; 41-46.

49. BOSTON AG, GOHH RY, BAUSSERMAN L et al. - Serum cystatin C as determinant of fasting total homocysteine levels in renal transplant recipients with normal serum creatinine. J AM Soc Neprol 1999; 10: 164-166.

50. HEINECKE JW, ROSEN H, SUZUKI LA et al. - The role of sulfurcontaining amino acids in superoxide production and modification of low density lipoprotein by arterial smooth muscle cells. J Biol Chem 1987; 262: 10098- 10103.

51. DUDMAN NP, HICKS C, WANG J \& WILCKEN DE - Human arterial endothelial cell detachment in vitro: its promotion by homocysteine and cysteine. Atherosclerosis 1991; 91: 77-83.

52. GRAEBER JE, SLOTT JH, ULANE RE et al. - Effect of homocysteine and homocystine on platelet and vascular arachidonic acid metabolism. Pediatr Res 1982; 16: 490-493.

53. WANG J, DUDMAN NP \& WILCKEN DE - Effects of homocysteine and related compounds on prostacyclin production by cultured human vascular endothelial cells. Thromb Haemost 1993; 70: 1047-1052.

54. PANGANAMALA RV, KARPEN CW \& MEROLA AJ - Peroxide mediated effects of homocysteine on arterial prostacyclin synthesis. Prostaglandins Leukot Med 1986; 22: 349-356.

55. STAMLER JS, OSBORNE JÁ, JARAKI O et al. - Adverse vascular effects of homocyst(e)ine are modulated by endothelium-derived relaxing factor and related oxides of nitrogen. J Clin Invest 1993; 91: 308-318.

56. HAJJAR KA - Homocyst(e)ine-induced modulation of tissue plasminogen activator binding to its endothelial cell membrane receptor. J Clin Invest 1993; 91: 2873-2879.

57. HAJJAR KA \& JACOVINA AT - Modulation of annexin II by homocysteine: implication for atherothrombosis. J Investig Med 1998; 46: 364-369.
58. RODGERS GM \& KANE WH - Activation of endogenous factor $\mathrm{V}$ by a homocysteine-induced vascular endothelial cell activator. J Clin Invest 1986; 77: 1909-1916.

59. RODGERS GM \& CONN MT - Homocysteine, an atherogenic stimulus, reduces protein $\mathrm{C}$ activation by arterial and venous endothelial cells. Blood 1990; 75: 895-901.

60. LENTZ SR \& SADLER JE - Inhibition of thrombomodulin surface expression and protein $\mathrm{C}$ activation by the thrombogenic agent homocysteine. J Clin Invest 1991; 88: 1906-1914.

61. NISHINAGA M, OZAWA T \& SHIMADA K - Homocysteine, a thrombogenic agent, suppresses anticoagulant heparan sulfate expression in cultured porcine aortic endothelial cells. J Clin Invest 1993; 92: 1381-1386.

62. BIA MJ - Nonimmunologic causes of late renal graft loss. Kidney Int 1995; 47: 1470-1480.

63. LINDHOLM A, ALBRECHTSEN D, FRODIN L et al. - Ischemic heart disease - major cause of death and graft loss after renal transplantation in Scandinavia. Transplantation 1995; 60: 451457.

64. KASISKE BL - Risk factors for accelerated atherosclerosis in renal transplant recipients. Am J Med 1988; 84: 985-992.

65. MACHADO DJB, COCUZZA CS, PAULA FJ et al. - Despite cyclosporine renal transplant patients have hyperhomocysteinemia. In: ANNUAL MEETTING AND SCIENTIFIC EXPOSITION, $32^{\text {nd }}$, Miami Beach, Florida, USA, 1999.

66. MAYRER G, LOOSLI HR, SCREIER E et al. - Disposition of cyclosporine in several animal soecies and man. Drug Metabol Dispo 1984; 12: 120.

67. WOODSIDE JV, FOGARTY DG, LIGHTBODY JH et al. Homocysteine and B- group vitamins in renal transplant patients. Clin Chim Acta 1999; 282 (1-2):157-166.

68. GILFIX BM, CANTAROVICH M, ELSTEIN E et al. - Relationship between cyclosporine, creatinine, and homocysteine in cardiac transplant patients. In: ANNUAL SCIENTIFIC MEETING, $18^{\text {th }}$, Chicago, Illinois, USA, 1999

69. MAZOUZ H, PRUNA A, WESTEEL PF et al. - Relationship between hyperhomocystinemia and azathioprine therapy in kidney graft recipients. In: CONGRESS OF THE EUROPEAN SOCIETY FOR ORGAN TRANSPLANTATION, $9^{\text {th }}$, Oslo, Norway, 1999.

70. KIM MH, KIM E, PASSEN EL et al. - Cortisol and estradiol: nongenetic factors for hyperhomocyst(e)inemia. Metabolism 1997; 46: $247-249$.

71. QUIROGA I, MORRIS-STIFF G, BABOO R et al. - Is homocysteine an important risk factor for the transplant recipient? In: CONGRESS OF THE EUROPEAN SOCIETY FOR ORGAN TRANSPLANTATION, $9^{\text {th }}$, Oslo, Norway, 1999.

Received for publication on the $08 / 05 / 00$ 